\title{
Preparing Waterfront Brownfields Redevelopment for Climate Change: the Water City Project, Almada (Portugal)
}

\author{
André Fernandes ${ }^{\dagger *}$, João Figueira de Sousa ${ }^{\dagger}$, Susana S. Brito ${ }^{\dagger}$, Bruno Neves ${ }^{\dagger}$, and Tânia Vicente Vin $^{\S}$ \\ ${ }^{\dagger}$ Interdisciplinary Centre of Social Sciences (CICS.NOVA) \\ Faculty of Social Sciences and Humanities (FCSH/NOVA) \\ Lisbon, Portugal \\ $\S$ Institute of Contemporary History \\ Lisbon, Portugal
}

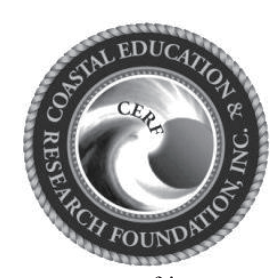

www.cerf-jcr.org

\begin{abstract}
Fernandes, A.; Figueira de Sousa, J.; Brito, S. S.; Neves, B., and Vicente, T., 2018. Preparing Waterfront Brownfields Redevelopment for Climate Change: the Water City Project, Almada (Portugal). In: Shim, J.-S.; Chun, I., and Lim, H.S. (eds.), Proceedings from the International Coastal Symposium (ICS) 2018 (Busan, Republic of Korea). Journal of Coastal Research, Special Issue No. 85, pp. 1531-1535. Coconut Creek (Florida), ISSN 07490208 .

The regeneration of former industrial complexes located in waterfronts represents an important challenge for several metropolitan areas worldwide. The effects of climate change combined with the fact that some brownfields are located in land-water interface areas make it necessary to evaluate this factor, particularly regarding adaptation to sea level rise (SLR). Focusing on the case of the Water City Project (Almada, Portugal), this article analyzes and discusses the measures proposed in order to strengthen the intervention area's resilience to SLR. It was possible to understand that the project: (i) was conceived to take into account the effects of SLR in the long-term; (ii) incorporates specific adaptation measures (mainly regulatory measures); (iii) combines accommodation and protection as response options to SLR.
\end{abstract}

ADDITIONAL INDEX WORDS: Brownfield regeneration, adaptation to climate change, sea level rise, Tagus Estuary.

\section{INTRODUCTION}

The regeneration of former industrial complexes situated in waterfronts represents an important challenge for several metropolitan areas worldwide. The challenges stem from the particularities of these sites, including: (a) their peripheral location in relation to the consolidated city and in the context of the metropolitan regions in which they are located (Costa, 2013; Fernandes, Figueira de Sousa, and Costa, 2016); (b) the large area to be intervened upon (Costa, 2013); (c) the need to solve existing environmental problems (Fernandes, Figueira de Sousa, and Costa, 2016); (d) the risk associated with their environmental conditions (Leger, Balch, and Garvin, 2016). The fact that these brownfields are located in land-water interface areas also make it necessary to consider a new and complex challenge for brownfield regeneration processes: the effects of climate change, particularly regarding sea level rise (SLR).

The recognition of the increasing risks and vulnerabilities due to the effects of SLR has led several cities to implement adaptation measures within the scope of climate change adaptation strategies, for example in London (Environment Agency, 2012; The City of London, 2010), Rotterdam (City of Rotterdam, 2013), New York (The City of New York, 2013; The City of New York, 2007), and Durban (Environmental Planning \& Climate Protection Department, 2014). Moreover, some urban waterfront plans and projects are adopting these types of

\footnotetext{
DOI: $10.2112 /$ SI85-307.1 received 30 November 2017; accepted in revision 10 February 2018.

*Corresponding author: andre.fernandes@fcsh.unl.pt

${ }^{\circ}$ Coastal Education and Research Foundation, Inc. 2018.
}

measures (e.g. New York, San Francisco, Rotterdam, Hamburg), while other cities are evaluating or implementing specific floodprevention infrastructures (e.g. St. Petersburg flood protection barrier, Venice flood barrier).

It is commonly recognized that climate change is likely to exacerbate natural risks in coastal areas (Leger, Balch, and Garvin, 2016; Rickey \& Houghton, 2009), which may determine different adaptation strategies for brownfield sites (Al-Tabbaa et al., 2007). However, the scientific discussion has been paying less attention to the way brownfield regeneration processes are incorporating measures to adapt and reduce the vulnerability of regenerated land to climate change impacts. Incorporating these measures is particularly important as regeneration involves longterm processes (Bartke, 2013) that are very risk-sensitive, either to real or perceived risks (Ferber and Grimski, 2002). Furthermore, brownfield regeneration requires an integrated approach (Ferber, 2010; Tölle et al., 2009), a process that commonly involves high rehabilitation costs (Thornton et al., 2007). Moreover, as brownfield redevelopment should prepare the sites for future new uses (Ferber and Grimski, 2002; Grimski and Ferber, 2001; Paccagnan and Turvani, 2007), it represents an opportunity to integrate climate change concerns into spatial planning policies and, therefore, may contribute to increasing territorial resilience and reducing uncertainty regarding brownfield regeneration.

Based on the systematization of climate change adaptation good practices in the context of coastal and waterfront redevelopment processes (in particular regarding SLR effects), this article aims to analyze and discuss the measures proposed by the Water City Project ("Almada Nascente Urbanization Plan 
- Water City") in order to strengthen territorial resilience to SLR. This project, with an intervention area of about 115 ha (Figure 1 ), intends to promote the regeneration of a former industrial complex (Lisnave shipyards), located on the south bank of the Tagus Estuary (Municipality of Almada, near Lisbon).

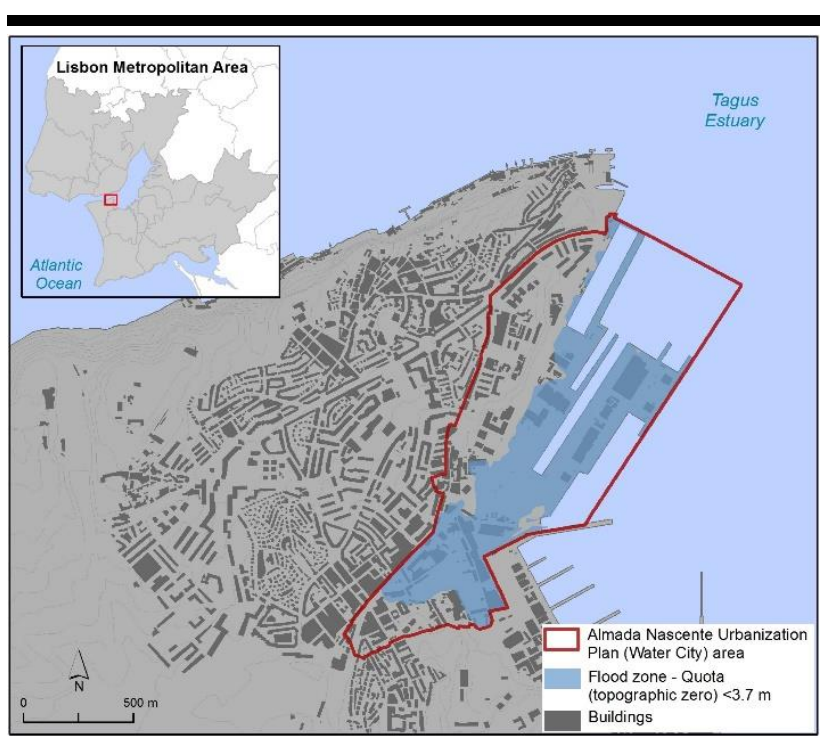

Figure 1. Almada Nascente Urbanization Plan - Water City Project area.

\section{Background: linking brownfield regeneration and climate change}

The regeneration of brownfield sites has become an important issue in planning policy (Maliene, Wignall, and Malys, 2012; Paccagnan and Turvani, 2007) as deindustrialization processes have resulted in the emergence of vacant and derelict land (Adams, De Sousa, and Tiesdell, 2010; Grimski \& Ferber, 2001). Worldwide, initially in North America and Europe, and subsequently in other industrialized regions, several brownfield redevelopment processes have been implemented. Despite this profusion of interventions, brownfield regeneration is commonly recognized as a complex process (EPA, 1999) requiring the development of different approaches depending on site characteristics (Ganser and Williams, 2007). The set of dimensions in the redevelopment of brownfield sites identified by the COBRAMAN project is an illustrative example of such complexity and include: an environmental dimension; project management; economic and financial dimension; technical solutions; legal dimension; social dimension; and, marketing (Tölle et al., 2009). In the same way, the framework model for sustainable brownfield redevelopment proposed by the EPA (1999) identifies ten key elements, which a sustainable brownfield redevelopment process should take into account (including risk management and environmental justice).

This analysis demonstrates that the environmental dimension is one of the critical issues in brownfield regeneration processes, mainly due to the environmental liabilities of contaminated sites. Apart from this "traditional approach" to the environmental dimension, it is also important to recognize that climate change represents a new challenge to brownfield regeneration processes.
As such, Al-Tabbaa et al. (2007) pointed out that climate change may mean that some sources of contamination that do not currently pose a significant risk to the environment, may be significant in the future. Moreover, challenges arising from climate change also include other effects, namely those resulting from SLR. This climate change consequence is particularly important since several brownfield sites worldwide are located on waterfronts. In this regard, it should be noted that industrial uses have had great relevance in urban waterfronts, namely those dependent on the maritime accessibility afforded by ports for the development of their activities (Fernandes, 2014), as in the case of former port facilities, manufacturing sites and military installations (Leger et al., 2016). Thus, in the case of brownfield sites located on waterfronts, planning policies and brownfield regeneration processes must necessarily address the new challenges posed by SLR (Fernandes, Figueira de Sousa, and Costa, 2016).

In this context, it is important not only to understand but also to systematize good practices regarding climate change adaptation, particularly those addressing SLR, and whether these are proposed or implemented in the framework of urban redevelopment projects or brownfield regeneration processes. Within this scope, a first approach comprises the role of spatial planning and spatial plans that support these types of processes, in order to strengthen territorial resilience to climate change effects. According to Carter and Sherriff (2011), the role of spatial planning in adapting to climate change is related to the following features: cross-boundary nature of spatial planning; long-term nature of spatial plans; influence over building design; influence over urban form; and, a forum for engagement. This set of features defines a framework that clarifies the importance of integrating adaptation to climate change in the planning of waterfront brownfield redevelopment processes. For instance, focusing on cross-boundary and long-term features, it is clear that brownfield regeneration projects should have the support of a strategic spatial planning approach, as they are key instruments for promoting adaptation to climate change. This is not only because they have a cross-boundary nature that should support adaptation agendas, but also because brownfield regeneration projects have long-term horizons and, therefore, operate within the time frame of those agendas. Furthermore, one must not neglect that planning processes are focused on the future, having the capacity to influence different systems (Hurlimann and March, 2012). In this way, brownfield regeneration projects also provide an opportunity for the construction of more resilient urban spaces, both from the standpoint of building design, as well as urban morphology/zoning, reducing territorial vulnerability and risks from climate change effects (including SLR). This is particularly relevant since land use and the configuration of urban space are increasingly recognized as factors that have implications for climate change adaptation (Davoudi, Crawford, and Mehmood, 2009).

A second approach comprises the systematization of planning tools applied to adaptation. According to the Davoudi approach, these tools can be summarized into the following three main types: pro-active interventions; regulatory interventions; and, strategic coordination (Davoudi, 2009). Depending on the nature of the regeneration intervention, it is possible to adopt these different types of tools, allowing an efficient articulation 
between the process of regeneration and the process of adaptation to climate change. This understanding matches the perspective of Klein et al. (2001), when they point out that an integrated coastal policy should minimize the potential for conflict between development objectives and adaptation objectives. In this context, it is also important to consider the specificities of the Portuguese planning system. Regarding this, a systematization proposal was recently presented, identifying four types of intervention through territorial planning to promote adaptation to climate change: strategic intervention (based on the definition of territorial development scenarios); regulatory intervention (based on legal and regulatory provisions regarding land use and building design); operational intervention (based on operational issues, such as the definition of provisions in priority interventions); and territorial governance (based on the participation of public, private and civil society actors) (Barroso, Gomes, and Telha, 2016).

Finally, a third approach concerns adaptation options. In general, the available options within the context of brownfield regeneration processes located on waterfronts do not differ from the typology of generic options that have been recognized by several authors (Bijlsma et al., 1996; IPCC, 1990; Klein et al., 2001; Nicholls et al., 2010; Tol, Klein, and Nicholls, 2008). As stated by Bijlsma et al. (1996), in the case of response strategies to SLR, the adaptation process can comprise one or more of the following options: (planned) retreat, accommodate, and protect. Moreover, one must bear in mind that a successful adaptation strategy should be tailored to the specific characteristics of the intervention area, mixing various adaptation options (Klein, Nicholls, and Mimura, 1999). This approach is supported by other authors, such as McGuire, according to whom there is a set of choices for coastal communities, which must take into account the specificities of the coastal area under consideration (McGuire, 2013).

\section{METHODS}

This research is focused on the Water City Project ("Almada Nascente Urbanization Plan - Water City"), a brownfield regeneration project that was selected as the empirical object for the following main reasons: (1) the intervention area of this project includes a brownfield that comprises the specific characteristics of a former industrial complex (i.e. Margueira area) located on a waterfront, with the consequent challenges of climate change (particularly SLR); (2) the project is supported by an urbanization plan ("Almada Nascente Urbanization Plan Water City”) approved in 2009 (Public Notice no. 1098/2009), even though the regeneration intervention has not yet begun; (3) it is an intervention whose importance is recognized in territorial management instruments, namely the "Regional Land Management Plan for the Lisbon Metropolitan Area", a document that aims at the reconversion of derelict industrial sites of the South bank of the Tagus Estuary (CCDRLVT, 2002); (4) it is also a project to which successive regional strategic instruments give special attention to, namely the regional strategy "Lisbon 2020" (CCDRLVT, 2007) where the regeneration of South bank brownfield sites is identified as a key intervention; (5) the project considers the local effects of SLR.

Bearing in mind the link between climate change adaptation and brownfield regeneration, and based on the systematization of adaptation measures in the context of brownfield regeneration processes, this article analyzes the measures proposed by the Water City Project. This analysis is supported by a qualitative approach, within which particular emphasis is given to the interpretation and discussion of the Water City Project, focusing on: (1) the methodology adopted by the project to estimate SLR; (2) the type of measures proposed in order to strengthen the intervention area's resilience to SLR.

\section{RESULTS}

By moving out from the Margueira area (Municipality of Almada) in 2000, the Lisnave shipyards freed up a space of around 50 ha in a waterfront brownfield site with a central location in the Tagus Estuary region (Figure 2). This process presents an opportunity for an extensive vacant area to be revitalized with new uses and functions, involving an intervention area of about 115 ha (Fernandes, 2015). In this way, "Almada Nascente Urbanization Plan - Water City" was approved in 2009, aiming to develop a deactivated industrial area through the creation of a new urban centrality in the Lisbon Metropolitan Area.

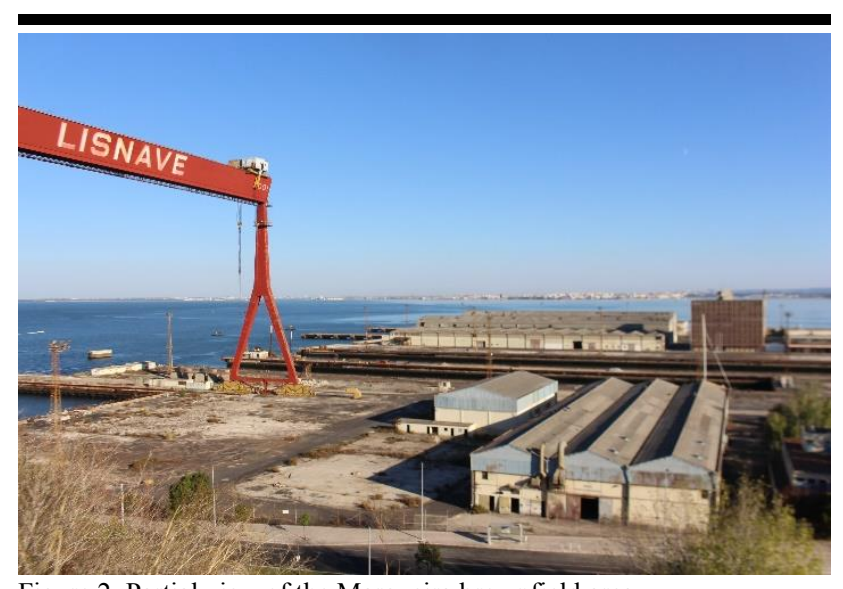

Figure 2. Partial view of the Margueira brownfield area.

The Urbanization Plan is based on the following strategic components: a place to work (by attracting new commercial and service activities); a place of connection with water (by promoting the functional relationship with the Tagus Estuary); a place to live (by offering support for novel forms of living and urban development); a place of culture (by creating new cultural facilities and increasing the offer of cultural events); a place of knowledge (by promoting the development of scientific and technological activities) (Atkins, Santa-Rita Arquitectos, and Richard Rogers Partnership, 2009a).

Specifically, regarding flood risks in the intervention area, the preparatory works of the Urbanization Plan recognized SLR and surface runoff of the drainage basin as determinants of occurrence of those risks (Atkins, Santa-Rita Arquitectos, and Richard Rogers Partnership, 2009b). The delimitation of the flood zone was based on the applicable Portuguese legislation and on two scenarios of SLR. The flood zone considered by the Water City Project corresponds to the most precautionary scenario, with a return period that is expected to exceed 100 
years. This scenario has been determined by pondering the effects of various phenomena - including tides, atmospheric disturbance, river floods and SLR - and their parameters: (1) a maximum high-tide of $+4.28 \mathrm{~m}$ (hydrographic zero); (2) an increase of $+0.54 \mathrm{~m}$ in sea level resulting from meteorological factors (100-year return period); (3) an increase of $+0.10 \mathrm{~m}$ in sea level due to flooding from the Tagus river; (4) a SLR of $+1.00 \mathrm{~m}$. The limit of the flood zone defined through the application of these criteria is $5.9 \mathrm{~m}$. However, since the hydrographic zero near the project intervention area is $2.20 \mathrm{~m}$ below the adopted mean sea level, a $3.7 \mathrm{~m}$ quota (topographic zero) was applied to delimit the flood zone (Atkins, Santa-Rita Arquitectos, and Richard Rogers Partnership, 2009b) - Figure 1.

Given the risks in the flood zone, the Project established a set of restrictions on land occupation, which are intended to minimize the impacts of SLR, including: (1) the construction of new buildings with a lower floor below the $3.7 \mathrm{~m}$ quota is not allowed (only car park floors are allowed below this quota, providing construction elements to prevent the overtopping of a $3.7 \mathrm{~m}$ flood are included); (2) in already built plots, reducing the surface area of open spaces at ground level is not allowed (e.g. surface of patios, gardens, etc.), unless provided for in development instruments of the "Almada Nascente Urbanization Plan - Water City"; (3) in existing buildings, any modification to their current use that involves the occupation of ground floors with housing is not permitted whenever the ground level is below the $3.7 \mathrm{~m}$ quota; (4) in plots yet to be built, public places must be kept permeable, and their occupation with any building, equipment or structure that results in an increase in the impermeability index is not allowed; (5) hospitals, schools, seclusion, emergency and emergency management equipment may only occupy plots with vacant ground areas above the $3.7 \mathrm{~m}$ quota; (6) public space interventions should prioritize the use of materials that minimize land impermeability; (7) in the landwater interface technical solutions should be implemented to minimize the effects of potential overtopping caused by waves (Public Notice no. 1098/2009).

\section{DISCUSSION}

The analysis of the Water City Project highlights some relevant issues linked to the problem of adapting to SLR in the context of brownfield regeneration processes. The first issue concerns the fact that the project was conceived considering the effects of SLR (flood zone) in the long-term, supported by a methodological approach in consultation with the former entity responsible for water resource management in the Tagus Estuary (i.e. the Tagus Regional Hydrographic Administration). A second issue is the incorporation of specific adaptation measures in the Regulation of Urbanization Plan (Public Notice no. 1098/2009), which aims to minimize the effects of flood events (especially those caused by SLR). Considering the previously analyzed proposals for systematizing the types of intervention through territorial planning, it is possible to conclude that the measures proposed by the Water City Project are essentially regulatory interventions (i.e. based on legal and regulatory provisions regarding land use and building form). A third issue is related to the adaptation options embodied in the measures proposed by the project. In this case, and taking into account the systematization proposed by Bijlsma et al. (1996), the Water
City Project combines the accommodate (e.g. in already built plots, reducing surface area of open spaces at ground level is not allowed) and protect options (e.g. technical solutions that minimize the effects of potential overtopping caused by waves should be implemented).

\section{CONCLUSIONS}

Addressing the effects of climate change (more precisely the effects of SLR), and applying precautionary adaptation measures (with an emphasis on regulatory measures), the Water City Project is an interesting example of how waterfront brownfield regeneration processes can incorporate climate change adaptation. Furthermore, based on the results obtained in this article, it will be important to develop a comparative analysis with other waterfront brownfield site interventions, in order to understand and systematize the different adaptation strategies and approaches in the context of these intervention processes. This should contribute to the establishment of a reference framework for the management of climate change adaptation within the context of brownfield redevelopment processes.

\section{ACKNOWLEDGMENTS}

The work presented in this article was funded by Fundação para a Ciência e Tecnologia (FCT/MCTES) (Grant SFRH/BPD/110975/2015, co-funded by the European Social Fund and POPH) and supported by CICS.NOVA Interdisciplinary Centre of Social Sciences of the Universidade Nova de Lisboa (UID/SOC/04647/2013), with the financial support of FCT/MCTES through National funds.

\section{LITERATURE CITED}

Adams, D.; De Sousa, C., and Tiesdell, S., 2010. Brownfield development: a comparison of North American and British approaches. Urban Studies, 47(1), 75-104.

Al-Tabbaa, A.; Smith, S.; De Munck, C.; Dixon, T.; Doak, J.; Garvin, S., and Raco, M., 2007. Climate Change, Pollutant Linkage and Brownfield Regeneration. In: Dixon, T.; Raco, M.; Catney, P., and Lerner, D.N. (eds.), Sustainable Brownfield Regeneration: Liveable Places from Problem Spaces. Oxford: Blackwell Publishing, pp. 265-313.

Atkins; Santa-Rita Arquitectos, and Richard Rogers Partnership, 2009a. Plano de Urbanização de Almada Nascente Relatório Síntese. Almada: C. M. Almada, 43p.

Atkins; Santa-Rita Arquitectos, and Richard Rogers Partnership, 2009b. Plano de Urbanização de Almada Nascente Relatório Ambiental. Almada: C. M. Almada, 76p.

Atkins; Santa-Rita Arquitectos, and Richard Rogers Partnership, 2009c. Plano de Urbanização de Almada Nascente - Guia de Desenho Urbano. Almada: C. M. Almada, 75p.

Barroso, S.; Gomes, H., and Telha, J., 2016. Manual Integração das Opções de Adaptação nos Instrumentos de Gestão Territorial de Âmbito Municipal. Amadora: Agência Portuguesa do Ambiente, 34p.

Bartke, S., 2013. Improving brownfield regeneration - a sustainable land take solution. Science for Environment Policy, 39, 3-4.

Bijlsma, L.; Ehler, C.N.; Klein, R.J.T.; Kulshrestha, S.M.; McLean, R.F.; Mimura, N.; Nicholls, R.J.; Nurse, L.A.; Nieto, H.P.; Stakhiv, E.Z.; Turner, R.K., and Warrick, R.A., 
1996. Coastal zones and small islands. In: Watson, R.T.; Zinyowera, M.C., and Moss, R.H. (eds.), Climate Change 1995 - Impacts, Adaptations and Mitigation of Climate Change: Scientific-Technical Analyses. New York: Cambridge University Press, pp. 289-324.

Carter, J., and Sherriff, G., 2011. Spatial Planning for Climate Change Adaptation: identifying cross cutting barriers and solutions. Manchester: Centre for Urban and Regional Ecology, University of Manchester, 48p.

CCDRLVT, 2002. Plano Regional de Ordenamento do Território da Área Metropolitana de Lisboa. Lisboa: CCDRLVT, 152p.

CCDRLVT, 2007. Lisboa 2020. Uma Estratégia de Lisboa para a Região de Lisboa. Lisboa: CCDRLVT, 144p.

City of Rotterdam, 2013. Rotterdam Climate Change Adaptation Strategy. Rotterdam: City of Rotterdam, $137 \mathrm{p}$.

Costa, J.P., 2013. Urbanismo e Adaptação às Alterações Climáticas - As Frentes de Água. Lisboa: Livros Horizonte, $184 p$.

Davoudi, S., 2009. Framing the Role of Spatial Planning in Climate Change. Newcastle: School of Architecture, Planning and Landscape - Newcastle University, 34p.

Davoudi, S.; Crawford, J., and Mehmood, A., 2009. Climate Change and Spatial Planning Responses. In: Davoudi, S.; Crawford, J., and Mehmood, A. (eds.), Planning for climate change: strategies for mitigation and adaptation for spatial planners. London: Earthscan, pp. 7-18.

Environment Agency, 2012. Thames Estuary 2100 - Managing flood risk through London and the Thames estuary. London: Environment Agency, 226p.

Environmental Planning \& Climate Protection Department, 2014. Durban Climate Change Strategy. Durban: Environmental Planning \& Climate Protection Department, $42 p$.

EPA, 1999. A Sustainable Brownfields Model Framework. Washington, DC: EPA, EPA500-R-99-001, 132p.

Ferber, U., 2010. Brownfield Integrated Governance - BRING (Baseline Study - Development Phase). Leipzig: s.1., 86p.

Ferber, U., and Grimski, D., 2002. Brownfields and Redevelopment of Urban Areas. Wien: Federal Environment Agency, 137p.

Fernandes, A., 2014. Dinâmicas de Revitalização de Frentes Ribeirinhas no Período Pós-Industrial: o Arco Ribeirinho Sul do Estuário do Tejo. Lisboa, Portugal: Universidade Nova de Lisboa. Ph.D. dissertation, 762p.

Fernandes, A., 2015. Progetti di recupero di aree industriali dismesse sull'Estuario del Tago. Transporti \& Cultura, $\mathrm{XV}(41), 60-67$.

Fernandes, A.; Figueira de Sousa, J., and Costa, J.P., 2016. Desafios contemporâneos das frentes de água: regeneração urbana e adaptação às alterações climáticas. In: Marín, R.G.; Sarría, F.A.; Serrato, F.B., and Muñoz, D.M. (eds.), Actas $X V$ Coloquio Ibérico de Geografía (Murica, España), pp. 159-168.

Ganser, R., and Williams, K., 2007. Brownfield development: are we using the right targets? Evidence from England and Germany. European Planning Studies, 15(5), 603-622.

Grimski, D., and Ferber, U., 2001. Urban brownfields in Europe. Land Contamination \& Reclamation, 9(1), 143-148.
Hurlimann, A.C., and March, A.P., 2012. The role of spatial planning in adapting to climate change. WIREs Climate Change, 3(5), 477-488.

IPCC, 1990. Climate Change: The IPCC Response Strategies. Report of the Response Strategies Working Group of the Intergovernmental Panel on Climate Change. Geneve: World Meteorological Organization and United Nations Environment Programme, 273p.

Klein, R.J.T.; Nicholls, R.J., and Mimura, N., 1999. Coastal adaptation to climate change: can the IPCC technical guidelines be applied?. Mitigation and Adaptation Strategies for Global Change, 4(3-4), 239-252.

Klein, R.J.T.; Nicholls, R.J.; Ragoonaden, S.; Capobianco, M.; Aston, J., and Buckley, E.N., 2001. Technological options for adaptation to climate change in coastal zones. Journal of Coastal Research, 17(3), 531-543.

Leger, C.; Balch, C., and Garvin, S., 2016. Understanding the planning challenges of brownfield development in coastal urban areas of England. Planning Practice \& Research, 31(2), 119-131.

Maliene, V.; Wignall, L., and Malys, N., 2012. Brownfield regeneration: waterfront site developments in Liverpool and Cologne. Journal of Environmental Engineering and Landscape Management, 20(1), 5-16.

McGuire, C.J., 2013. Adapting to Sea Level Rise in the Coastal Zone: Law and Policy Considerations. Boca Raton: CRC Press, 211p.

Nicholls, R.; Brown, S.; Hanson, S., and Hinkel, J., 2010. Economics of coastal zone: adaptation to climate change. Washington, DC: World Bank, Discussion Paper no. 10, $48 \mathrm{p}$.

Paccagnan, V., and Turvani, M., 2007. The reuse of urban brownfields in Europe: a law and economics analysis. SIDE-ISLE $3^{\text {rd }}$ Annual Conference (Milan, Italy), $24 \mathrm{p}$.

Public Notice no. 1098/2009, D.R. 2. ${ }^{\text {a }}$ Série 218, 45811-45834 (2009-11-10).

Rickey, B., and Houghton, J., 2009. Solving the riddle of the sands: regenerating England's seaside towns. Journal of Urban Regeneration and Renewal, 3(1), 46-55.

The City of London, 2010. Rising to the Challenge - The City of London Climate Change Adaptation Strategy. London: The City of London, $42 \mathrm{p}$.

The City of New York, 2007. PlaNYC - A Greener, Greater New York. New York: The City of New York, 156p.

The City of New York, 2013. PlaNYC - A Stronger, More Resilient New York. New York: The City of New York, 438p.

Thornton, G.; Franz, M.; Edwards, D.; Pahlen, G., and Nathanail, P., 2007. The challenge of sustainability: incentives for brownfield regeneration in Europe. Environmental Science \& Policy, 10(2), 116-134.

Tol, R.S.J.; Klein, R.J.T., and Nicholls, R.J., 2008. Towards successful adaptation to sea-level rise along Europe's coasts. Journal of Coastal Research, 24(2), 432-442.

Tölle, A.; Jeleszyńska, D. M.; Tadych, J., and Jasińska, M., 2009. Report about concepts and tools for brownfield redevelopment activities. Bydgoszcz: University of Economy, 116p. 